\title{
ФIНАНСИ
}

УДК: 336.2: 342.25

JEL Classification: G 40; HOO

\author{
СНікіфоров П.О., Качур Т.І., 2021 \\ p.nikiforov@chnu.edu.ua \\ Чернівецький національний університет імені Юрія Федьковича, Чернівиі
}

\section{РЕАЛІЗАЦІЯ КОНЦЕПЦІЇ ПОВЕДІНКОВИХ ФІНАНСІВ У ДОСЛІДЖЕННЯХ ТРАНСФОРМАЦІЙ СФЕРИ ПУБЛІЧНИХ ФІНАНСІВ}

\begin{abstract}
Аналізуються теоретичні засади науки публічних фінансів, з наголосом на їх конщептуалізацію в дискурсі теорії поведінкової економіки та біхевіористичних фінансів. Зазначено, щзо у вітчизняній науці з проблематики публічних фінансів домінує аналіз формально-інституціональних трансформацій фіскальної сфери, а пануюча антропоцентрична парадигма більшу увагу приділяє розвитку теоретичних ідей, особливо міждисциплінарних зв'язків фінансового знання.

Наголошено, щзо сучасна концепція біхевіористичних фінансів аналізує поведінкові упередження суб'єктів прийняття фінансових рішень у сфері приватних фінансів, а в статті доводиться, щзо $і$ у сфері публічних фінансів діють теоретичні підходи біхевіористичних фінансів, а ия наука зобов 'язана вводити в аналіз сучасних трансформачій у сфері публічних фінансів теоретичні надбання поведінкових фінансів.

Ключові слова: публічні фінанси, поведінкова економіка, біхевіористичні фінанси, філософія екзистенціолізму, суб'єктивістська теорія вартості, парадигма теорії публічних фінансів, ірраціональна поведінка, антропоцентризм, поведінкові упередження.
\end{abstract}

Постановка проблеми. У вітчизняній фінансовій та в цілому економічній науці (i відповідній літературі) останніми роками все ширше застосовується термін «публічні фінанси», на відміну від терміна «державні фінанси» як теоретичного релікту радянської наукової спадщини. Обговорення проблематики саме публічних фінансів у дискурсі їх суттєвості (онтологіі), структурних складових, особливостей формування бюджетів різних рівнів, співвідношення у фінансовому сенсі повноважень та діяльності центральних органів влади та місцевого самоврядування значно стимулювалося розвитком процесів фіскальної децентралізації. Проте і сьогодні у вітчизняній фінансовій науці практично відсутне більш-менш однозначне трактування поняття публічних фінансів та його структурних складових.

Водночас серед багатьох, так званих гетеродоксальних течій економічної теорії протягом XXI сторіччя набула значного розвитку «поведінкова економіка» - новий науковий напрям, у рамках якого на засадах міждисциплінарності обгрунтовуються закономірності, причини та наслідки прийняття ірраціональних економічних рішень на основі інформаційної асиметричності та під впливом поведінкових упереджень, які формуються у специфічних умовах сприйняття й опрацювання інформації суб'єктами прийняття рішень зі специфічними соціально-психологічними характеристиками.

Сьогодні проблематика поведінкової економіки, a разом із нею проблематика поведінкових (біхевіористичних) фінансів дає змогу розглядати сучасні економічні процеси та явища 3 позиції ірраціональності у поведінці людини. У вітчизняній фінансовій науці існують небагато публікацій, які стосуються поведінкових фінансів виключно на мікрорівні, де аналізуються фінансові рішення на рівні окремого суб'єкта приватних фінансів в рамках його поведінки а фінансових ринках. Ми вважаємо, що в теоретичному плані необхідно доводити проблематику біхевіористичних фінансів до макрорівня, до аналізу трансформаційних процесів у сфері публічних фінансів. Наша гіпотеза дослідження полягає в тому, що й у сфері публічних фінансів діють теоретичні підходи, визначаються практичні аспекти власне поведінкових фінансів і теорія публічних фінансів зобов'язана як наука (система знань) обов'язково вводити в аналіз сучасних трансформацій сфери суспільних (публічних) фінансів теоретичні надбання біхевіористичних фінансів.

Аналіз останніх досліджень і публікацій. Різні автори вітчизняної науки теоретизують публічні фінанси на основі окремих та різних критеріальних ознак (або сукупності декількох), наприклад, таких найбільш поширених, як їх 
цільове призначення, способи формування ресурсів, форми власності, транспорентність функціонування, онтологічна суттєвість окремих складових сфери публічних фінансів $[1 ; 2 ; 3 ; 4 ; 5$; 6]. Проте питання еволюції теорії публічних фінансів i, особливо, їх концептуалізація в дискурсі поведінкової економіки потребують додаткового дослідження. Водночас, у вітчизняній науці останнім часом спостерігається підвищений інтерес саме до теорії поведінкової економіки в цілому та, зокрема, до біхевіористичних (поведінкових фінансів) [8;9; $10 ; 13 ; 14]$. Більше того, останніми роками постійно зростає інтерес до окресленої проблематики, до питань еволюції теорії публічних фінансів, їх наукової концептуалізації, у т.ч. у дискурсі поведінкових фінансів.

Виділення не розв'язаних раніше частин загальної проблеми. Сучасна вітчизняна наука, присвячена проблематиці публічних (державних) фінансів, як правило, зосереджується на формально-інституціональних трансформаціях фінансово-бюджетної системи, хоча, на наш погляд, необхідно концентрувати увагу на розвитку теоретичних ідей, особливо у частині міждисциплінарних взаємозв'язків, взаємозалежностей фінансового знання. Академічна спільнота у сфері науки публічних фінансів та практикуюче політичне середовище намагаються, як правило, i теоретизувати, i практично реалізувати фундаментальні постулати, особливості i цінності політико-економічного устрою розвинених західних країн: ринкової економіки, плюралістичної демократії, правової держави, громадянського суспільства.

Отже, якщо у вітчизняній науці державних фінансів абсолютно домінують дослідження трансформацій формальних інститутів (у першу чергу через законодавство) фіскальної сфери та аналіз іiі інституціонального потенціалу, то сучасна теорія публічних фінансів зобов'язана через аналіз національної специфіки здійснювати також етико-психологічне осмислення фінансових явищ $\mathrm{i}$ процесів у рамках поведінкових моделей суб'єктів сфери публічних фінансів, тобто на основі концепції поведінкових фінансів.

Формування цілей статті. Метою статті $\epsilon$ формулювання й обгрунтування у першому наближенні гіпотези, яка полягає у тому, що й у сфері публічних фінансів діють теоретичні підходи, визначаються практичні правила поведінкових фінансів, тобто сучасну біхевіористичну концепцію фінансів можна застосовувати не тільки в частині прийняття фінансових рішень суб'єктами приватних фінансів на фінансових ринках, але й у сфері публічних фінансів, при прийнятті фінансових рішень $\dddot{1 і ̈ ~ а г е н т а м и . ~}$

Виклад основного матеріалу дослідження. Україна у XXI столітті постійно наголошує, що вона є частиною європейської цивілізації. Наявні сьогодні гострі економічні та соціальні проблеми ставлять перед вітчизняною фінансовоекономічною думкою радикально важливі питання про шляхи стабілізації, точніше оздоровлення фінансової системи, наповнення державного бюджету, зміцнення національної валюти. Увага до сфери публічних (державних) фінансів акцентується ще й необхідністю на початку третього десятиріччя XXI століття в Україні глибокої перебудови як академічної, так i в цілому суспільної свідомості щодо суспільного сектору державного господарювання, створення правової держави, розвитку демократії. Надзвичайно актуальним за цих умов $є$ пошук оптимального співвідношення державницьких $\mathrm{i}$ суто приватних принципів життєдіяльності суспільства.

В Україні через фіскально-бюджетні канали акумулюються (централізуються та використовуються) кошти, еквівалентні приблизно 50\% вартості річного ВВП. Якщо половина національної економіки «пропускається» (вартісно) через сферу публічних фінансів, то, безумовно, це свідчить про надважливу роль держави не просто як регулятора економічних явищ та процесів, але і як економічного суб'єкта.

Сфера публічних фінансів допомагає пошуку великого компромісу між економічною ефективністю та соціальною справедливістю, вона являє собою приклад поступового поєднання економічно диференційованого суспільства із соціально однорідною державою. Усвідомлення та теоретичне i практичне розуміння такої держави здійснюється в поняттях публічних (суспільних) фінансів.

Історія розвитку науки публічних фінансів, тобто її теоретичної концептуалізації, свідчить, що біля ii витоків знаходяться ідеї та методи, запропоновані філософією, політичною економією та теорією держави, до яких були додані досягнення права, соціології, психології, економетрики та інших наук, і цей симбіоз був втілений у систему фінансового знання. Саме за участю цих наук i за допомогою власного теоретичного апарату та пізнавальноаналітичного інструментарію склались ті міждисциплінарні схеми, навіть парадигми мислення, якими оперує сучасна теорія публічних фінансів. 
Економічна методологія наголошує, що в соціальних і поведінкових науках ортодоксальне уявлення про поведінку раціональної «економічної людини» склалось під впливом позитивістських методів дослідження, запозичених із природознавства. Сам дух епохи Відродження вимагав від соціальних наук такої ж «науковості» системи знань (науки), яка була притаманна природничим наукам, і саме в цей період (XVIII сторіччя) формувалась політична економія як власне наука, i таке ії відгалуження як фінансове знання.

Водночас, уже у XIX ст. розвиток західної фінансової думки достатньо чітко показує, що гносеологічно починає домінувати антипозитивістський по суті екзистенціалізм як філософська течія та близька до нього філософська антропологія (принцип вивчення дійсності, неодмінною умовою якого $\epsilon$ присутність дослідника, з одного боку, та власне людини в самому об'єкті аналізу - 3 іншого). Філософія екзистенциалізму наголошує на увазі до людини, якій відводиться першорядне значення не стільки в іiі інтелектуальних потенціях, скільки в морально-етичних імперативах. Совість, справедливість, свобода, відповідальність, - $з$ одного боку, з іншого - місце і роль людини в суспільстві як особистості та діяльністного суб'єкта - це визначальна тема екзистенціалізму, який у філософському сенсі $є$ формою самоосмислення і самодіяльності людини при всіх обставинах. Саме подібні погляди впливають на розуміння публічних фінансів, хоча би у тому сенсі, що якості політичних діячів мають суттєво важливе значення, бо вони приймають найважливіші рішення у сфері суспільних (публічних) фінансів.

Під впливом філософії екзистенціалізму формувався біхевіористичний напрямок у дослідженнях фінансів та в цілому творився той пізнавальний потенціал фінансової науки, який значно розширив сам предмет науки фінансів. У дискурсі публічних (суспільних) фінансів традиційні питання, фінансового знання були скореговані на врахування людського фактору фінансових явищ. Саме такий суб'єктивний аспект досліджень фінансової сфери у західній фінансовій науці вітчизняний дослідник В. Л. Андрущенко називає «фінансовим антропологізмом i/aбо антропоцентризмом» [11, c. 22]. Завдяки антропоцентризму науки публічних фінансів предмет цієї наукової дисципліни «під'єднує», за висловом В. Л. Андрущенка, тобто залучає в предмет науки вивчення мотивів поведінки фізичних осіб як суб'єктів податково-бюджетних процесів: виборців, споживачів суспільних благ, податкоплатників, законодавців, державних службовців та ін.

У контексті аналізу різних моделей поведінки суб'єктів у процесі управління публічними фінансами нобелівський лауреат Джеймс Б'юкенен (один 3 найвидатніших теоретиків публічних фінансів), продовжуючи традицію італійської школи фінансової теорії, представники якої стояли у витоків науки публічних фінансів, звертався до законів етики у філософській системі I. Канта. За Б’юкененом, надважливим принципом при прийнятті рішень у сфері публічних фінансів виступає знаменитий етичний імператив Канта, за яким суб'єкти публічних фінансів мають вести себе так, щоб їхня поведінка могла стати загальним моральним правилом. У Б'юкенена ця етична максима Канта стала складовою частиною його теорії суспільного вибору, ій повинна відповідати поведінка всіх людей, причетних до здійснення фінансових операцій та фінансової політики у сфері суспільних (публічних) фінансів, а морально-етичний дискурс повинен обов'язково стати частиною досліджень в економічній науці [12].

Історія розвитку науки публічних фінансів свідчить, що поступово, ще у XIX - на початку $\mathrm{XX}$ ст. у ній були сформовані три базових теоретичних концепти, три своєрідних «ядра» науки, на яких базується фундамент теоретичного каркасу публічних фінансів. Такими базовими концептами теоретичної конструкції цієї науки виступають:

1) теорія суспільних благ (потреб);

2) теорія фіскального обміну;

3) теорія суспільного вибору

Якщо ідеалістичні підходи у дослідженнях публічних фінансів виявляють себе в ролі морально-етичних критеріїв фінансових явищ $\mathrm{i}$ процесів, а ще як мотивація стану суспільних фінансів - і це реалізується в теорії суспільного вибору, то матеріалістичний дискурс у розумінні публічних фінансів базується на інтересі, на вигодах: фіскальних - для державних структур (реалізуються в теорії фіскального обміну), споживчо-перерозподільних - для споживачів бюджетних ресурсів, наприклад, суб'єктів системи соціальних допомог (реалізуються в теорії суспільних благ і в теорії фіскального обміну).

Від філософського ідеалізму та матеріалізму пролягає шлях до інших ідейно-теоретичних засад наукового осмислення публічних фінансів. Історія розвитку політичної економії свідчить, що в останній третині XIX ст. 3 появою суб'єктивістської теорії вартості відбувся науковий переворот не тільки в системі 
політичної економії, але й у теорії публічних фінансів, адже ця теорія радикально змінила $\mathrm{i}$ збагатила теоретичну інтерпретацію сфери публічних фінансів. Відомий український історик фінансової думки В. Андрущенко слушно при цьому зауважує, що: «...теорія модифікує парадигму свого розвитку - тобто, по суті приймає іншу концептуальну структуру розуміння, пояснення та оцінки фінансових реалій» [11, с. 25]. По суті суб'єктивістська теорія вартості (цінності) - це теорія індивідуального ставлення споживачів до цінності для себе і меж користування тими чи іншими благами. А цінність (вартість) ресурсів виражає відношення між благом і потребою в ньому в суб'єктивному сприйнятті споживача, і це для теорії публічних фінансів адекватно пояснює ставлення до створених державою благ, фінансованих за рахунок бюджетних коштів.

Отже, суб'єктивістська теорія завжди залишається актуальною для науки публічних фінансів як цілісна, логічно послідовна теоретична система, яка адекватно трактує поведінку людей в умовах ринку і політичної представницької демократії, а також їх ставлення до фіскальних інститутів держави у податковобюджетних процесах. Саме суб'єктивістськопсихологічне пояснення вартості (цінності) благ та прив'язка фінансових проблем до парадигми суб'єктивної теорії вартості вивели науку про публічні фінанси на той «мейнстримний» шлях, який в світовій науці і сьогодні залишається панівним та за своєю концептуальною цінністю таким, що найбільш реально та правильно пояснює природу фінансових явищ і вибір фінансової політики.

Важлива частина теорії публічних фінансів закладена в політичній філософії та державознавстві, в рамках яких обгрунтовуються та законодавчо формуються ті компоненти фінансового знання, які пов'язані з податковою системою, 3 бюджетним процесом та іншими процедурами прийняття фінансових рішень, тобто і з здійсненням заходів, у яких поєднуються елементи економіки і політики. Розуміння того, що держава через податки, бюджетні видатки i державний кредит реалізує свої функції, керуючись при цьому i позаекономічними мотивами, загальноприйнятне й у соціальних науках, і у державній практиці.

У структурі публічних фінансів власне фінанси втрачають частину свого економічного змісту, проте набувають в значній мірі соціальнополітичних характеристик. Тут політична філософія та політологія значно спрощують доктрини економічної науки та й узагалі, дуже часто виступають як теоретичні постулати базових взаємодій суб'єктів суспільних фінансів, ігноруючи постулати економічної в цілому та фінансової, зокрема, науки.

Отже, за визначенням, публічні фінанси мають неоднорідну онтологічну природу у розумінні поєднання державницьких i суто економічних моментів, а тому, завжди виходячи iз суто практичних проблем, можна по-різному інтерпретувати оптимальні масштаби державної діяльності, обгрунтовувати різну міру та способи втручання чи невтручання держави у соціальноекономічні процеси в країні.

Ринковий економічний механізм і сьогодні в науці подається як своєрідна несуча конструкція всієї системи задоволення приватних і в значній мірі суспільних потреб. Проте наука давно констатувала, що ринковому механізму іманентно властиві вади, або провали ринку, тобто його неспроможність задовольняти окремі нагальні суспільні потреби - ринок загалом неефективний у забезпеченні оборони, правопорядку, захисту довкілля, він не працює в системі соціального захисту тощо. Проте, 3 іншого боку, «держава загального добробуту», яка через бюджетне фінансування соціальних програм забезпечує безкоштовне користування основними соціальними благами, також відчуває i «провали держави». Саме такі «провали» за Дж. Б'юкененом, в рамках його теорії суспільного вибору означають, що в умовах представницької демократії парламенти часто розробляють i схвалюють такі соціальні програми, які скоріше відповідають популістським демагогічним гаслам чи політичним амбіціям, ніж реальним потребам громадян і можливостям національної економіки.

Безумовно, у XXI сторіччі розуміння ролі держави, у розвинутому світі зазнало суттєвих змін, в першу чергу, під впливом фіскальної кризи «держави загального добробуту», яка неспроможна навіть у найбагатших країнах виконувати взяті на себе завищенні фінансові зобов'язання перед своїм населенням без стрімкого зростання державних боргів. Одним 3 важливих напрямків трансформації публічних фінансів розвинутих країн, у тому числі для подолання фіскальної кризи, став процес фіскальної децентралізації - перерозподіл повноважень i фінансових ресурсів між центральним урядом та органами місцевого самоврядування на користь останніх під лозунгом наближення влади до людей. У теоретичному плані процес децентралізації підкреслює той суттєво важливий факт, що оптимальні моделі мінімізації бюджетів i раціонального використання коштів не можуть бути реалізовані 
поза інституціональними механізмами суспільного вибору та прийняття рішень, а такі механізми діють більш ефективно на ближчому для людей рівні.

Отже, сучасна теорія публічних фінансів постійно займається пошуком (при врахуванні національної специфіки) рівноваги між можливостями ринку і можливостями держави, пошуками балансу між провалами ринку i провалами держави, пошуками оптимального співвідношення між централізацією і децентралізацією бюджетних ресурсів. При цьому біхевіористична концепція пронизує всю теоретичну систему публічних фінансів, акцентуючи на тому, що у сфері економіки державна бюрократія повинна в якомога більшій мірі бути замінена власним інтересом і творчістю сукупності індивідуумів, а у сфері політики саме держава повинна забезпечувати права і свободи, соціальні гарантіі, правовий захист власності, національну безпеку при контролі 3 боку громадянського суспільства.

Поєднання економіки i політики в науці публічних фінансів свідчить, що аналіз оподаткування, бюджетних видатків, державного боргу (податкових i позикових фінансів у бюджетному процесі) здійснюється за допомогою інструментів економічної науки, а поведінка суб'єктів податково-бюджетного процесу - в поняттях політології, соціології, психології, державознавства.

А взагалі, в цілому, завдяки антропоцентризму, суб'єктивізму в науці публічних фінансів не тільки проводиться аналіз інституціональних трансформацій та наголошується на посиленні інституціонального потенціалу держави (цей підхід абсолютно домінує у вітчизняній фінансовій науці), але i «здійснюється етично-психологічне осмислення, у фокусі якого знаходяться люди - діючі особи фінансових явищ i процесів» [11, с. 37]. Світоглядні особливості, стереотипи мислення, мотивації поведінки різних народів, їх «соціальна пам'ять» завжди «входили» в предмет науки публічних фінансів протягом всієї історії їі розвитку.

У сучасних вітчизняних умовах, у рамках розвитку української державності відбуваються суттєві трансформації системи фінансових взаємовідносин суспільства та політичної влади (як на загальнонаціональному, так і на місцевому рівнях). Саме сфера публічних фінансів як поєднання економіки і політики в найбільшій мірі реалізує взаємодію влади і суспільства, саме вона допомагає суспільству трансформуватись у суб'єкт політико-економічних відносин, наділеного і можливостями, i правами у діях 3 подолання важливих соціально-економічних проблем, які заважають розвитку суспільства.

У цьому сенсі наукове осмислення й оцінка ролі поведінкової економіки в системі взаємодії влади і суспільства виступає необхідною умовою подальшого розвитку науки публічних фінансів. Ми вже наголошували на початку статті, що сьогодні проблематика поведінкової економіки, а разом 3 нею проблематика поведінкових (біхевіористичних) фінансів виступає як новий науковий напрямок, який базується на постулатах багатьох соціально-гуманітарних наук i на засадах міждисциплінарності обгрунтовує закономірності, причини та наслідки прийняття економічних і управлінських рішень у результаті діï ірраціональних чинників, під впливом поведінкових упереджень психо-емоційного змісту.

Безумовно, як i окрема людина, так i суспільство в цілому не завжди демонструють раціональну економічну поведінку через фактичну невизначеність потреб і недостовірну оцінку необхідної інформації, інформаційну асиметричність. Саме економічний і політичний суб'єкт публічних фінансів із власними інтересами i потребами, який може думати ірраціонально, виступає важливим елементом i поведінкової економіки в цілому, і поведінкових фінансів, зокрема.

Р. Талер як один із засновників теорії поведінкової економіки наголошував, що остання - це існуюча навколо нас економіка, проте іiі аналіз суттєво збагачений знаннями у сфері психології та інших соціальних наук [7]. У вітчизняній науці також спостерігається останнім часом підвищений інтерес до поняття «поведінкова економіка» [8; 9; 10]. Домінує підхід, за яким така економіка як напрям науки досліджує особливості i наслідки впливу емоційних, когнітивних і соціальних чинників на процес прийняття рішень за умов обмеженої раціональності на будь-якому рівні економічної системи суспільства [8]. Наголошується також, що завдяки знанню основних причин нераціональної поведінки економічних суб'єктів можна передбачати i контролювати таку поведінку та уникати їі негативних наслідків [9].

В Україні даний напрям досліджень розвинений явно недостатньо, хоча існують усі умови для формування позитивних змін у суспільстві завдяки базовим концептам теорії поведінкової економіки, наприклад, у сфері публічних фінансів, у процесі фіскальної децентралізації [10].

У вітчизняній фінансовій науці існують малочисельні публікації, які стосуються поведінкових фінансів винятково на мікрорівні, 
де аналізуються фінансові рішення на рівні суб'єктів підприємницької діяльності, бізнесових одиниць, підприємств у рамках їх поведінки на ринках у сфері приватних фінансів $[13 ; 14]$. Поведінкові фінанси тут виступають інструментом виявлення поведінкових упереджень учасників фінансових відносин та ідентифікації їх причин. Узагалі, сьогодні біхевіористичні фінанси набувають широкого практичного застосування, особливо, наголосимо на цьому, у сфері фінансових ринків та інвестиційних стратегій. Наприклад, широко застосовуються в зарубіжній інвестиційній практиці схеми виявлення цінних паперів, які $€$ об’єктами поведінкових упереджень інших учасників фінансового ринку. Водночас можна констатувати, що в українській практиці фінансовий менеджмент підприємств практично не враховує поведінкові аспекти, які б протидіяли різної природи упередженням вітчизняних економічних суб'єктів.

Проте, на наш погляд, сьогодні необхідно доводити проблематику біхевіористичних фінансів до макрорівня та досліджувати трансформаційні процеси у сфері публічних фінансів сучасної України під впливом вищеназваних чинників ірраціональної поведінки економічних і політичних агентів, які, як виборці, податкоплатники, споживачі суспільних благ, політики, державні службовці тощо приймають різноманітні рішення на різних рівнях по формуванню та використанню суспільних фінансових ресурсів. Наша попередня гіпотеза, доведення якої вимагає подальших досліджень, якраз і полягає в тому, що й у сфері публічних фінансів діють теоретичні підходи, визначаються практичні правила та навички власне поведінкових фінансів, тобто біхевіористичну концепцію фінансів можна застосовувати на макрорівні, у сфері публічних фінансів.
Висновки. Безумовно, як свідчить історія розвитку науки публічних фінансів, під впливом філософії екзистенціалізму, філософської антропології, антропоцентризму вже в останній третині XIX та першій третині XX століття цілком сформувався біхевіористичний напрямок у теорії публічних фінансів, проте він розумівся як парадигма пануючої теоретичної інтерпретації публічних фінансів, де в центрі системи науки стояла людина раціональної поведінки, суб'єкт входив у сам предмет науки, обов'язковою була присутність дослідника і власне людини в об'єкті аналізу. Це $\epsilon$, на наш погляд, «старим» розумінням біхевіористичних фінансів, i, зауважимо, історично першим таке розуміння ролі поведінкових фінансів прийшло в науку зі сфери публічних фінансів, на чому i наголошується в даній статті.

Сучасне, «нове» розуміння концепції біхевіористичних фінансів базується на застосуванні в аналізі поведінкових моделей різних суб'єктів прийняття фінансових рішень саме ірраціональних чинників, формуванні різноманітних поведінкових упереджень тощо.

Якраз таке «нове» розуміння поведінкових фінансів повинно стати складовою пануючої антропоцентристської парадигми публічних фінансів, в рамках якої і повинні здійснюватися дослідження подальших трансформацій сфери публічних (суспільних) фінансів. У сучасній Україні такі дослідження фіскальної сфери вимагають чіткого визначення та врахування власне національних поведінкових особливостей прийняття фінансових рішень суб'єктами публічних фінансів, визначення та систематизації поведінкових упереджень працівників фінансових структур - учасників податковобюджетних процесів, та їх урахування в розробці та реалізації фіскальної політики. Такого роду дослідження саме i треба очікувати від вітчизняної фінансової науки.

\section{Список літератури}

1. Абакуменко О. В., Височина А. В. Змістовні та організаційно-функціональні особливості публічних фінансів в Україні. Вісник Сумського державного університету. Серія Економіка. 2017. № 2, С. 13-19.

2. Бойко С. Публічні фінанси у контексті генези та еволюції понятійно-категоріального апарату фінансової науки. Економіст. 2015. № 10, С. 31-35.

3. Длугопольський О. В. Суспільний сектор економіки і публічні фінанси в епоху глобальних трансформацій : монографія. Тернопіль : Екон. думка, THEУ, 2011. $632 \mathrm{c}$.

4. Куценко Т. Ф. Публічні фінанси в Україні : зміст та структура 3 урахуванням сучасних тенденцій розвитку. Економіка та держава. 2016. № 6, С. 62-66.

5. Луніна I. О., Бондарук Т. Г. Еволюція теорії та наукова концепція публічних фінансів. Фінанси України. 2019. № 8, С. 26-44.

6. Опарін В. Н., Федосов В. Н., Юхименко П. І. Публічні фінанси : генеза, теоретичні колізії та практична концептуалізація. Фінанси Украӥни. 2017. № 2, C. 110-128.

7. Талер Р. Новая поведенческая экономика. Почему люди нарушают правила традиционной экономики и как на этом заработать. М. : Эксмо, 2017. $368 \mathrm{c}$.

8. Чернобай Л., Широн Ю. Поведінкова економіка : сутність та підходи до визначення. Психологічні виміри культури, економіки, управління. 2016. Вип. 8, С.71-78. 
9. Солодухін С. В., Шайтанова С. С. Сучасні підходи до аналізу впливу поведінкових факторів в управлінні економічними об'єктами. Науковий вісник Ужгородського національного університету. Серія : Міжнародні економічні відносини та світове господарство. 2017. Вип. 15. Ч. 2, С. 129-132.

10. Буряченко А. С., Левченко К. М. Поведінкова економіка та децентралізація бюджетної системи. Фінанси Украӥни. 2019. № 9, С. 27-42.

11. Андрущенко В. Л. Фінансова думка Заходу у XX столітті. (Теоретична концептуалізація і наукова проблематика державних фінансів). Львів : Каменяр, 2000 . $303 \mathrm{c}$.

12. Нікіфоров П. О. Морально-етичний дискурс в економічних дослідженнях як об'єктивна вимога розвитку науки. Економічний та управлінський потенціал соціалізації економіки : монографія / за заг. ред. 3. І. Галушки / Чернівці : Черн. нац. ун-т. ім. Ю. Федьковича, 2020. С. 106-112.

13. Кузьмук С. Г. Досвід практичного застосування біхевіористичної концепції у фінансах та особливості його використання в Україні. Сучасні тенденції інституціональних трансформацій фінансової системи України : кол. монографія / за заг. ред. П. О. Нікіфорова. Чернівці : Технодрук, 2018. С. 168-179.

14. Нікіфоров П. О., Кузьмук С. Г. Економічна людина та біхевіористична концепція теоретичних досліджень у фінансовій науці. Науковий вісник Чернівецького університету. Економіка: зб. наук. пр. Чернівці : Черн. нац. ун-т ім. Ю. Федьковича, 2016. Вип. 773-774, С. 3-7.

\section{References}

1. Abakumenko, O.V. and Vysochyna, A.V. (2017), "Substantive and organizational and functional features of public finance in Ukraine", Visnyk Sumskoho derzhavnoho universytetu. Seriia: Ekonomika, no. 2, pp. 13-19.

2. Boyko, S. (2015), "Public finances in the context of the genesis and evolution of conceptual and categorical apparatus of financial science", Ekonomist, no. 10, pp. 3135.

3. Dluhopolskyi, O.V. (2011), Suspilnyi sektor ekonomiky $i$ publichni finansy $v$ epokhu hlobalnykh transformatsii [The Suspension Sector of Economy and Public Finance in the Age of Global Transformations], Ekonomichna dumka, TNEU, Ternopil, Ukraine.

4. Kutsenko, T.F. (2016), "Public finance in Ukraine: content and structure considering current tendencies of devlipment", Ekonomika ta derzhava, no. 6, pp. 62-66.

5. Lunina, I.O. and Bondaruk ,T.H. (2019), "The development of theory and scientific concept of public finance", Finansy Ukrainy, no. 8, pp. 26-44.

6. Oparin, V.N., Fedosov, V.N. and Yukhymenko, P.I. (2017), "Public finances: genesis, theoretical and practical conceptualization collision", Finansy Ukrainy, no. 2, pp. 110-128.

7. Taler, R. (2017), Novaia povedencheskaia эkonomyka. Pochemu liudy narushaiut pravyla tradytsyonnoi эkonomyky y kak na эtom zarabotat [New behavioral economics. Why do people violate the rules of the traditional economy and how to make money on it], Эksmo, Moscow, Russia.

8. Chernobai, L. and Shyron, Yu. (2016), "Behavioral economics: essence and approaches to definition", Psykholohichni vymiry kultury, ekonomiky, upravlinnia, issue 8, pp. 71-78.

9. Solodukhin, S.V. and Shaytanova, E.S. (2017), "Modern approaches to the analysis of the influence of behavioral factors in the management of economic objects", Naukovyi visnyk Uzhhorodskoho natsionalnoho universytetu. Seriia: Mizhnarodni ekonomichni vidnosyny ta svitove hospodarstvo, , issue 15, part 2, pp. 129-132.

10. Buriachenko, A.Ye. and Levchenko, K.M. (2019), "Behavioral economy and decentralization of the budget system", Finansy Ukrainy, no. 9, pp. 27-42.

11. Andrushchenko, V.L. (2000), Finansova dumka Zakhodu u KhKh stolitti. (Teoretychna kontseptualizatsiia $i$ naukova problematyka derzhavnykh finansiv) [Western financial thought in the twentieth century. (Theoretical conceptualization and scientific issues of public finance)], Kameniar, Lviv, Ukraine.

12. Nikiforov, P.O. (2020), "Moral and ethical discourse in economic research as an objective requirement for the development of science " in Halushka, Z.I. (ed.), Ekonomichnyi ta upravlinskyi potentsial sotsializatsii ekonomiky [Economic and managerial potential of socialization of the economy], Chernivetskyi natsionalnyi universytet imeni Yuriia Fedkovycha, Chernivtsi, Ukraine, pp. 106-112.

13. Kuzmuk, S.H. (2018), "Experience of practical application of the behavioral concept in finance and features of its use in Ukraine" in Nikiforov, P.O. (ed.), Suchasni tendentsii instytutsionalnykh transformatsii finansovoi systemy Ukrainy [Modern tendencies of institutional transformations of the financial system of Ukraine], Tekhnodruk, Chernivtsi, Ukraine, pp. 168-179.

14. Nikiforov, P.O. and Kuzmuk, S.H. (2016), "Economic man and behavioral concept of theoretical research in financial science", Naukovyi visnyk Chernivetskoho universytetu. Ekonomika: zbirnyk naukovykh prats, issue 773-774, pp. 3-7.

\section{РЕАЛИЗАЦИЯ КОНЦЕПЦИИ ПОВЕДЕНЧЕСКИХ ФИНАНСОВ В ИССЛЕДОВАНИЯХ ТРАНСФОРМАЦИЙ СФЕРЫ ПУБЛИЧНЫХ ФИНАНСОВ}

Исследованы теоретические основы науки публичных финансов, с акцентом на их концептуализацию в дискурсе теории поведенческой экономики и бихевиористических финансов. Отмечено, что в отечественной науке публичньхх финансов доминирует анализ формально-институциональных трансформаџий фискальной 
сферы, хотя в рамках господствующей антропоцентричной парадигмы науки, необходимо также уделять внимание развитию теоретических идей, особенно в части междисциплинарных связей финансового знания.

Современное понимание поведенческих финансов касается только микроуровня, анализа поведения субъектов частных финансов на рынках. Но концепџия поведенческих финансов должна стать составляющей современной антропочентристской парадигмы публичных финансов, то есть и в этой сфере также действуют, при ее анализе, теоретические подходы, практические правила и навыки поведенческих финансов.

Ключевые слова: публичные финансы, поведенческая экономика, бихевиористические финансы, философия екзистенциолизма, субъективистская теория стоимости, парадигма теории публичных финансов, иррациональное поведение, антропоцентризм, поведенческие предубеждения.

Summary

Petro Nikiforov, Tatiana Kachur

\section{IMPLEMENTATION OF THE CONCEPT OF BEHAVIORAL FINANCE IN RESEARCH OF PUBLIC FINANCE TRANSFORMATION}

The article examines the theoretical foundations of the development of the public finance's science, with an emphasis on their conceptualization in the discourse of the theory of behavioral economics in general and behavioral finance in particular. It is noted that in modern domestic science devoted to the problems of public (state) finance, the analysis of formal-institutional transformations of the fiscal sphere and strengthening of the institutional potential of the state, although within the framework of the dominant anthropocentric paradigm in the theory of public finance, it is necessary, based on the postulates of modern science and national specifics, pay more and more attention to the development of theoretical ideas, especially in terms of interdisciplinary connections, interdependencies of financial knowledge.

The history of the development of the public finance's science testifies to the formation in it of the behavioristic direction as the core of the dominant anthropocentric paradigm of public finance's theoretical structure. But this was the "old" understanding of behaviorism, where a person of rational behavior was at the center of the science's system, and the "new" understanding of the concept of behavioristic finance is based on the use of various subjects of financial decision-making, irrational factors, and the formation of various behavioral biases in the analysis of behavioral models. At the same time, this understanding of behavioral finance concerns only the micro level, the analysis of the behavior of private finance entities in the markets. Such a "new" understanding of behavioral finance should become a component of the dominant anthropocentric paradigm of public finance, within which studies of further transformations in the sphere of public finance should be carried out. Our preliminary hypothesis, formulated and substantiated in the first approximation, is that in the field of public finance, theoretical approaches act in its analysis, and practical rules and skills of "new" behavioral finance are determined.

In modern Ukraine, fiscal research requires a clear definition and consideration of national behavioral characteristics of financial decision-making by public finance entities, identification and systematization of behavioral biases of participants in tax and budgetary processes, taking them into account in the development and implementation of fiscal policy.

Keywords: public finance, behavioral economics, behavioral finance, philosophy of existentialism, subjectivist theory of value, paradigm of public finance theory, irrational behavior, anthropocentrism, behavioral prejudices. 